$\begin{gathered}\text { EPiC Series in Education Science } \\ \text { Volume 1, 2017, Pages 305-315 }\end{gathered}$
$\begin{gathered}\text { AUBEA 2017: Australasian Universities Build- } \\ \text { ing Education Association Conference 2017 }\end{gathered}$

\title{
Modelling Green Technology Adoption Based on Sustainable Construction Practices
}

\author{
Mona Foroozanfar ${ }^{1}$, Samad M. Ebrahimzadeh Sepasgozar ${ }^{2}$ and \\ Hani Arbabi ${ }^{1}$ \\ ${ }^{1}$ Tarbiat Modares university, Tehran, Iran. \\ ${ }^{2} \mathrm{UNSW}$, Sydney, Australia. \\ mona.foroozanfar@gmail.com, Sepas@unsw.edu.au, \\ haniarbabi@yahoo.com
}

\begin{abstract}
New digital technologies have the potential to monitor the environmental footprint, mainly Carbon emissions. However, the construction projects slowly adopt such technologies only for monitoring the footprint and other sustainability purposes. Despite the government's policies and external pushes, the adoption decision for sustainability innovations largely depends on different stakeholders' behavior including developers, consultants, and contractors. This paper presents a novel conceptual model for green technology adoption regarding sustainability in the construction industry. This model is developed based on six main constructs include organizational facilitating conditions, expected performance, expected efforts, innovativeness, optimism, and user performance.

In order to develop the model, factors affecting the green technology adoption process are identified, a questionnaire is designed, and an empirical investigation is conducted to collect data from construction companies. Regression analysis is utilized to analyze the data using SPSS. The findings show the importance of a series of factors influencing sustainable technology adoption. Based on the extensive review on the relevant literature, few empirical studies have been conducted to examine the proposed constructs sustainable technology. The results are also providing a guidance to broaden understanding of users' adoption behavior within this context and thereby increasing the chances for successful adoption of sustainable technology and develop activity-level.
\end{abstract}

\section{Introduction}

Legislated regulations of different governments for protecting the environment put the construction industry under pressure to consider the principles of sustainability. Organizations should decide to apply 
new technologies and meet sustainability requirements in all process of the project life cycle to be competitive in the industry (Petri, Beach, Rezgui, Wilson, \& Li, 2014).

Digital technology is known beneficial for sustainable practices particularly in the construction and maintenance period (Cheng \& Das, 2014). For instance, Because of the integrative character of BIM (Building Information Management), it is an appropriate technology to implement sustainable strategies in construction industry (Hammond, Nawari, \& Walters, 2014). Despite all the mentioned benefits of digital technology, the process of sustainable construction technology adoption (SCTA) is slow in construction. Therefore, the aim of this paper is to identify key factors influencing the construction participants' decisions to implement a green technology through development of the sustainable construction technology adoption (SCTA) model. Studies on SCTA is scarce, previous studies mainly focused on construction technology adoption covering a wider range of technologies (Son, Lee, \& Kim, 2015; Succar \& Kassem, 2015), while the literature ignored to particularly focus on sustainable technologies.

The paper first systematically reviews the relevant literature. It follows with presenting how the literature of digital technology applications is growing while the number of publications focus on green technologies has remained constant in the last three years. In this study, TAM (Technology Acceptance Model) was used to investigate the green technology adoption in construction industry; TAM was extended to SCTA model to include organizational facilitating conditions, innovativeness, optimism, and user performance. Next, the research design and approach is presented. Finally, the results of the study are discussed.

\section{Literature Review}

\subsection{A Systematic Review of Technology Clusters}

A systematic review is conducted to identify the publication trends and to clarify the gap in the literature of digital construction technology. All papers from five selected journals were reviewed and analyzed. The papers were classified into two main clusters: non-green technology and green technology.

None-green technology refers to non-green specific technology cluster included the papers which were about the digital technologies such as a description about them, their advantages, disadvantages, their applications in the construction industry, and their acceptance model while none of these technologies were toward sustainability goals.

Green technology cluster refers to a collection of papers that were about the green and sustainable digital technologies application, features, advantages and disadvantages and the consequences of their usage and the impact of their utilization on the reduction of environmental issues.

Figure 1 demonstrates the number of papers in two non-green specific technology and green-based technology clusters in three recent years. It illustrates swift increase in the amount of non-green specific technology researches from 2014 to 2016. By technology improvement, it can be predictable that, this growing trend will continue in next years; but, despite of the increasing attention of the public and companies to sustainable development, this figure shows that, the focused researches on green technologies are insignificant, also Figure 2 shows that number of researches in the field of green specific technology is limited in compared to non-green specific technology; therefore, given the importance of applying green specific technology, researchers should be encouraged to pay more attention to it in construction industry. The results of this review presented that conducted researches in the field of green building technologies are limited and no research has been done on the application of this technologies in construction industry. 


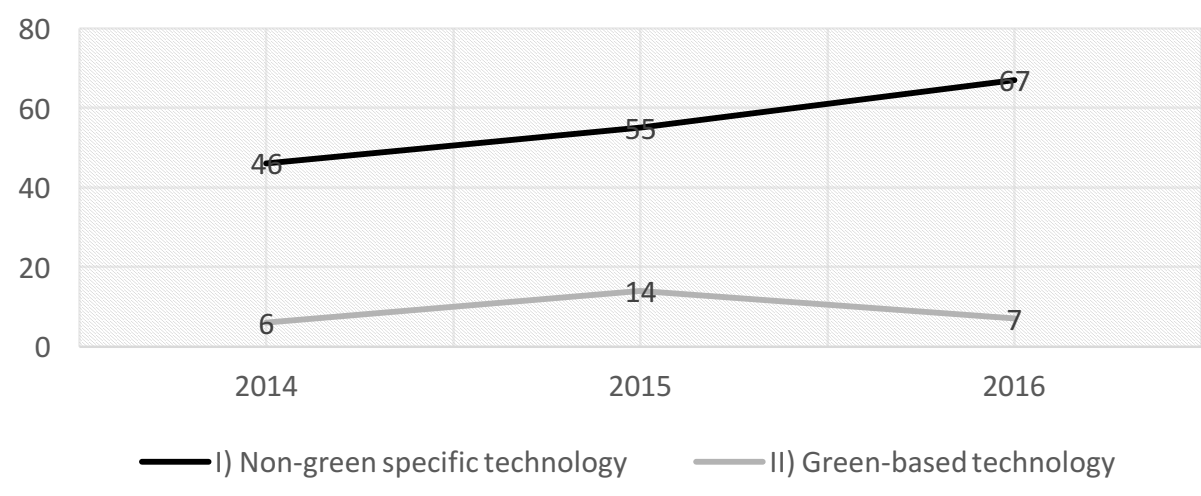

Figure 1: Total number of related publications in last three years

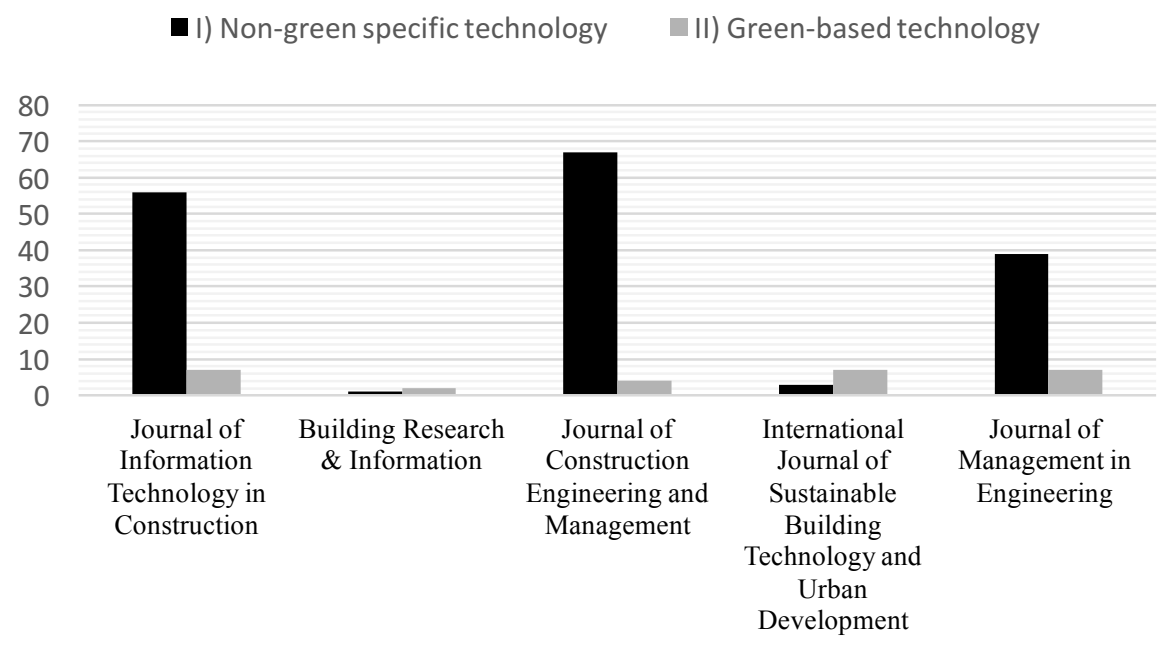

Figure 2: Related publications in the selected journals

According to the reviewed papers, following four main themes were recognized: 1) Off-line digital technologies; 2) BIM based technologies; 3) Web-based technologies; and 4) Green technologies, which are reviewed in next sections. Four themes are identified in the reviews which are summarized in Table 1. 


\begin{tabular}{|c|c|c|}
\hline Theme & Definition & Example \\
\hline $\begin{array}{l}\text { Theme 1: } \\
\text { Off-Line } \\
\text { Program }\end{array}$ & $\begin{array}{l}\text { Technology which } \\
\text { related to various } \\
\text { disciplines integrated } \\
\text { utilization such as } \\
\text { computer science and } \\
\text { architecture science } \\
\text { (Yang, 2011) }\end{array}$ & $\begin{array}{l}\text { CAAD for computer graphic drawing and } \\
\text { editing graphics by electronic stylus (Yang, } \\
\text { 2011) }\end{array}$ \\
\hline $\begin{array}{l}\text { Theme 2: } \\
\text { BIM Based } \\
\text { Technologies }\end{array}$ & $\begin{array}{l}\text { It's a set of innovative } \\
\text { technology, processes } \\
\text { and policies that } \\
\text { influence on the } \\
\text { deliverables, } \\
\text { relationships and roles } \\
\text { of the industry (Succar } \\
\text { \& Kassem, 2015) }\end{array}$ & $\begin{array}{l}\text { Create and use digital models, for } \\
\text { designing construction and managing } \\
\text { operation of the construction process and } \\
\text { finally performing the project life } \\
\text { management (Jiang \& Lei, 2014) }\end{array}$ \\
\hline $\begin{array}{l}\text { Theme 3: } \\
\text { Web-Based } \\
\text { Technology }\end{array}$ & $\begin{array}{l}\text { World Wide Web } \\
\text { technology which is } \\
\text { available over the } \\
\text { internet and enable us to } \\
\text { communicate and } \\
\text { exchange information } \\
\text { and access to data via } \\
\text { internet (Feng, 2006) }\end{array}$ & $\begin{array}{l}\text { Quadcopter that enables project } \\
\text { managers to monitor the site, maintain the } \\
\text { asset (Irizarry, Gheisari, \& Walker, 2012; } \\
\text { Snow, 2016). } \\
\text { Virtual reality that include real life images } \\
\text { building structures in different } \\
\text { environmental status can be analysed } \\
\text { (Setareh, Bowman, \& Kalita, 2005; Zhao \& } \\
\text { Lucas, 2015) }\end{array}$ \\
\hline $\begin{array}{l}\text { 4: Green } \\
\text { Construction } \\
\text { Technology }\end{array}$ & $\begin{array}{l}\text { The technologies which } \\
\text { are used to achieve } \\
\text { sustainability objectives } \\
\text { in construction industry } \\
\text { (Chan, Darko, Ameyaw, } \\
\text { \& Owusu-Manu, 2016). }\end{array}$ & $\begin{array}{l}\text { They help to analyse the sustainable } \\
\text { building performance such as daylighting, } \\
\text { energy efficiency and sustainable materials } \\
\text { (Ibrahim, 2013). }\end{array}$ \\
\hline
\end{tabular}

Table 1: Descriptions of each identified theme

\subsection{Gap in Digital Technology Literature}

While main clusters are discussed in this section, further review shows that there are three main directions in the literature regarding to technology studies: a) technology development, b) technology adoption, and c) technology implementation.

The first one is based on experiments to create new prototypes for presenting it to the construction industry or improving the accuracy and quality of common technology. The second direction introduces or applies models which are sketched based on the appointed knowledge framework such as socioeconomic and psychological models. For instance, Son et al. (2015) argued that two distinct constructs (usefulness and ease of use) are positively related to an individual's behavioral intention to apply a new technology in construction. The third direction concentrates on the way of operation of the innovative technology for resolving a peculiar obstacle in construction. For example, Wang and Cao (2010) reviewed key project-level factors that affect IT performance and analyzed the way these factors 
influence IT adaption in construction industry. In another paper, the user-based innovative construction technologies implementation in Australia is studied (Shelton, Martek, \& Chen, 2016).

To investigate the influential factors on construction stakeholders' decisions for digital technology adoption, studding its limitations and challenges is an important issue which can be categorized in to the technology challenges and the problems of the digital technology' implementation. The limitations of digital technology and suggested improvements for removing them are presented in Table 2.

\begin{tabular}{|c|c|c|c|}
\hline \multirow{4}{*}{ 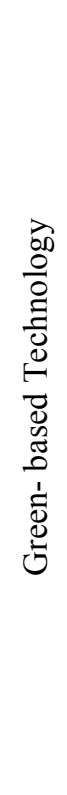 } & Theme & $\begin{array}{l}\text { Focus and Current } \\
\text { Direction }\end{array}$ & Limitation and Suggested Improvement \\
\hline & $\begin{array}{l}\text { Theme 1: Off- } \\
\text { Line Program }\end{array}$ & $\begin{array}{l}\text { To develop a simulation } \\
\text { tool for predicating } \\
\text { carbon emission by } \\
\text { virtual prototyping } \\
\text { technologies (Wong et } \\
\text { al., 2013) }\end{array}$ & $\begin{array}{l}\text { The current tools cannot } \\
\text { monitor construction mechanisms and } \\
\text { evaluate the sensitivity of planning } \\
\text { schedules }\end{array}$ \\
\hline & $\begin{array}{c}\text { Theme 2: BIM } \\
\text { Based } \\
\text { Technologies }\end{array}$ & $\begin{array}{l}\text { To generate } \\
\text { documentation } \\
\text { necessary required for } \\
\text { green building } \\
\text { certification (Illhan \& } \\
\text { Yaman, 2016) }\end{array}$ & $\begin{array}{l}\text { Limited to only a group of } \\
\text { the BREEAM materials and compatible } \\
\text { with ArchiCAD }{ }^{\circledR} \text { software }\end{array}$ \\
\hline & $\begin{array}{l}\text { Theme 3: Web- } \\
\text { Based } \\
\text { Technology }\end{array}$ & $\begin{array}{l}\text { To develop BIM-based } \\
\text { web platform for green } \\
\text { building services such } \\
\text { as energy simulation } \\
\text { and code checking } \\
\text { (Cheng \& Das, 2014) } \\
\end{array}$ & $\begin{array}{c}\text { Technically limited functions are } \\
\text { delivered and cannot cover critical } \\
\text { qualitative factors such as human } \\
\text { comfort }\end{array}$ \\
\hline
\end{tabular}

Table 2: The application of digital technologies in two major groups: a) green-based; and b) non-green specific technologies

Other challenges of technology adoption include: difficulty in learning and complexity in usage, requiring computer knowledge, rework problems due to data entry, cost, too many functionalities, less user-friendly characteristics, and low efficiencies are reported as key causes of the tardy technology uptake. Researches showed that disability to apply some of the technology in the primary stages of their implementation and incoherence analysis tools with key software, doubt and mistrust in data sources, industrial and institutional realized barriers, can prevent its widespread application (Lin, 2010; Petri et al., 2014; Yang, 2011).

\section{The Proposed Model of Sustainable Construction Technology Adoption (SCTA)}

SCTA models is proposed based on the initial technology acceptance model (TAM) developed by Davis (1993). TAM includes two main constructs: perceived usefulness and perceived ease of use 
influencing the adoption user's behavioral intention (Venkatesh \& Davis, 2000). Figure 3 presents the SCTA model and the relevant hypothesized relationships.

In this paper, we divided the factors affecting users' willingness to accept a new green technology into three main attributes: individual, organizational and the effects of the technology areas.

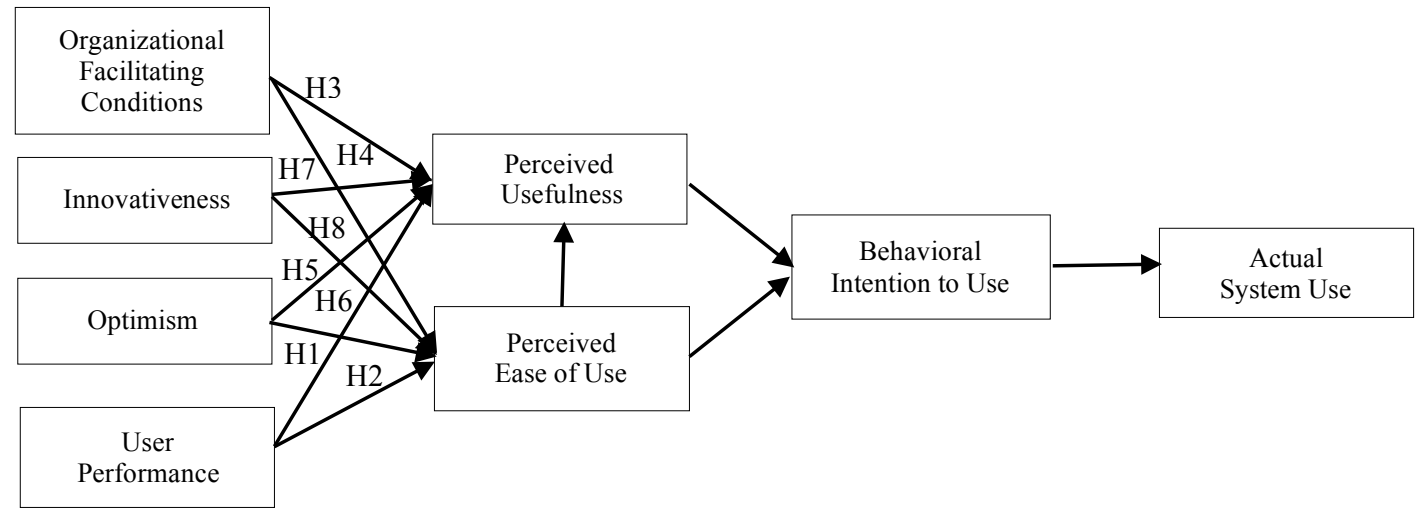

Figure 3: SCTA model of sustainable technology adoption 


\begin{tabular}{|c|c|c|}
\hline Constructs & Definition & Related Hypotheses \\
\hline $\begin{array}{c}\text { User } \\
\text { Performance }\end{array}$ & $\begin{array}{l}\text { The proficiency of a user in executing a duty, } \\
\text { which refers to the precision and pace } \\
\text { aggregated over acts presented in the period } \\
\text { of a task (Nicosia, Oulasvirta, \& Kristensson, } \\
\text { 2014). }\end{array}$ & $\begin{array}{l}\text { H1. User performance } \\
\text { has a positive relationship } \\
\text { on perceived usefulness. } \\
\text { H2. User performance has a } \\
\text { positive relationship on } \\
\text { perceived ease of use. }\end{array}$ \\
\hline $\begin{array}{l}\text { Organizational } \\
\text { Facilitating } \\
\text { Conditions } \\
\text { Toward } \\
\text { Sustainability }\end{array}$ & $\begin{array}{l}\text { Individual understanding about the } \\
\text { accessibility of technological and } \\
\text { organizational resources, such as } \\
\text { opportunities, knowledge, and resources } \\
\text { which can eliminate the barriers of applying } \\
\text { a system (Venkatesh, Morris, Davis, \& } \\
\text { Davis, 2003). } \\
\text { The comprehend availability of needed } \\
\text { resources to apply the target technology, If } \\
\text { support or preventive organizational factors } \\
\text { for the use of the technology change, this } \\
\text { environmental change should be reflected } \\
\text { (Park, Lee, \& Yi, 2011). }\end{array}$ & $\begin{array}{c}\text { H3. Organizational } \\
\text { facilitating conditions } \\
\text { toward sustainability affects } \\
\text { positively on perceived } \\
\text { usefulness. } \\
\text { H4. Organizational } \\
\text { facilitating conditions } \\
\text { toward sustainability affects } \\
\text { positively on perceived ease } \\
\text { of use. }\end{array}$ \\
\hline Optimism & $\begin{array}{l}\text { A positive opinion about the technology and } \\
\text { believing that by technology people can have } \\
\text { a life with more control, flexibility, and } \\
\text { proficiency. By optimism people feel } \\
\text { positively about technology (Godoe \& } \\
\text { Johansen, 2012). }\end{array}$ & $\begin{array}{l}\text { H5. Optimism is related } \\
\text { to perceived usefulness } \\
\text { positively. } \\
\text { H6. Optimism is related } \\
\text { to perceived ease of use } \\
\text { positively. }\end{array}$ \\
\hline Innovativeness & $\begin{array}{l}\text { Individuals' preference to be a technology } \\
\text { leader, shows people realization about } \\
\text { themselves as being a pioneer in technology } \\
\text { adoption (Godoe \& Johansen, 2012). }\end{array}$ & $\begin{array}{l}\text { H7. Innovativeness has a } \\
\text { positive effect on perceived } \\
\text { usefulness positively. } \\
\text { H8. Innovativeness has a } \\
\text { positive effect on perceived } \\
\text { ease of use positively. }\end{array}$ \\
\hline
\end{tabular}

Table 3: Constructs of the SCTA model

Since using a green technology, increase the users' efficiency in different fields such as sustainability, the user would prefer to use it. It is hypothesized that user performance can affect the technology adoption. If the organizational condition is prepared for using the sustainable technology; for example, the senior manager encourages toward sustainability and if needed resources such as sustainability software and standards are provided, the user will tend to apply the green technology; so, we hypothesized that organizational facilitating conditions toward sustainability will have the positive effect on green technology utilization.

Individuals' attitude toward the use of technology and sustainability issues impact on their willingness to use the green technology; therefore, optimistic users are more likely to use sustainable technology than pessimists. Hence, we hypothesized that optimism will have the positive effect on 
green technology utilization. Innovativeness refers to Innovative people who prefer to try new things such as new technologies, they are not afraid to take risks; so, they have a positive approach towards technology adoption. Therefore, the positive relationship between innovativeness and green technology usage was proposed.

\section{Research Method}

This paper studies different construction participants who use green digital technology in their projects. The survey is designed in two sections. In the first section demographic information such as gender, age, education level, job title, and tenure with the company was gathered. In the second section the respondents were asked to indicate their level of agreement with 42 different statements (the measurement items) on a five-point Likert type scale, with 1 displaying "strongly disagree" and 5 displaying "strongly agree" which were adapted from previous studies. These measurement items are grouped according to the six main constructs (organizational facilitating conditions, perceived usefulness, perceived ease of use, innovativeness, optimism, and user performance). For analysing the data to measure the relations of structures through significance values Regression analysis was done using SPSS. Finally, a number of open ended questions were asked from the respondents to express their opinions.

A total of 80 construction project participants from different construction companies were selected. Sustainable construction is a priority in these companies. A questionnaire was designed for data collection, sufficient description was provided to prevent the misinterpretation by respondents. All of the respondents had experience using sustainable construction digital technology. Of the respondents in the survey, about $53 \%$ were men and about $47 \%$ were women. $100 \%$ of the respondents had university degree. They were aged between $25-50$ years.

\section{Results}

In this study the effects of the four independent variables such as organizational facilitating conditions, innovativeness, optimism, and user performance on the internal factors are studied. At first the Cronbach's alpha was assessed to test the internal consistency as a measure of reliability for each sub-scale. Nunnally (1978), suggests that alphas above .70 for group analyses are acceptable. The Cronbach's alpha is .708 and it is acceptable and no item shouldn't be excluded.

The Regression analysis was also conducted to estimate the relationships among dependent and independent variables, if Sig. in Coefficient is less than 0.05, the correlation is meaningful. The Beta analysis shows the amount of dependent variable impact on independent variable.

The summary of the results of assessment from the Regression-analysis is illustrated in Table 4. Individual coefficients for the assumed relations among the variables showed that organizational facilitating conditions, innovativeness, optimism, and user performance have a significant influence on perceived usefulness and perceived ease of use; therefore, all of the hypothesis were supported by the results. Moreover, the strongest predictor of both perceived ease of use $($ Beta $=.543)$ and perceived usefulness $($ Beta $=.538)$ is optimism.

Accordingly, significant positive relationship between all the independent variables and perceived ease of use and perceived usefulness was detected. Based on the results, positive relationship between user performance and two dependent variables expresses that if a technology improve the performance of a user, he or she finds it more useful and if it could increase his or her efficiency it indicates that it is easy to use the technology. 
The positive relationship between optimism and two dependent variables means that optimism about the technology in people causes that they find it more useful and more easy to use.

\begin{tabular}{clcc}
\hline Independent Variables & Dependent Variables & Beta & Sig. \\
\hline Organizational Facilitating & Perceived usefulness & .285 & .003 \\
Conditions & Perceived usefulness & .338 & .002 \\
Optimism & Perceived usefulness & .538 & .000 \\
User Performance & Perceived usefulness & .401 & 001 \\
Organizational Facilitating \\
Conditions & Perceived ease of use & .247 & .004 \\
Innovativeness & Perceived ease of use & .383 & .001 \\
Optimism & Perceived ease of use & .543 & .000 \\
User Performance & Perceived ease of use & .299 & .003
\end{tabular}

Table 4: Results of the Regression analysis of independent variables and dependent variables

The significant positive relationship between organizational facilitating conditions and two dependent variables implies that if the needed technological and organizational resources are available, the individuals will encounter with fewer obstacles in the use of technology so they will find it more beneficial and easier to use.

The positive relationship between innovativeness and two dependent variables suggests that innovative individual can use a technology easily but unlike the findings of Godoe and Johansen (2012), the results show that innovativeness causes people has a positive opinion about the usefulness of a technology, maybe because of innovativeness they can apply the technology for different working goals and in their desired ways.

\section{Conclusion}

The paper is aimed to identify key factors influencing the implementation of sustainable technology in construction projects. A survey was conducted to measure the participants' perception towards new sustainable technologies. Sustainable technology refers to upgraded tools and equipment which can consider environmental concerns. Previous studies mainly focused on the technology adoption process, 
and have ignored to mainly study sustainable technologies (other than materials). This on-going study indicates that technology awareness and introduction to the market is the main key factor. In addition, organization attributes including their facility and readiness play an important role in the process of technology adoption. Furthermore, cultural change is required because the company would amplify individuals' innovativeness to apply new technologies in a right way. It also may influence their optimistic about the new technologies, since optimistic users find the new technology easy to use and more useful. The findings of the study are critical for the policy makers to understand how to facilitate the process of sustainable technologies in the industry. In addition, the findings of the study help sustainable technology vendors to get better understanding of their customers. The future direction of this study is to examine the proposed model using a large data set.

\section{Resources}

Chan, A. P. C., Darko, A., Ameyaw, E. E., \& Owusu-Manu, D.-G. (2016). Barriers Affecting the Adoption of Green Building Technologies. Journal of Management in Engineering. doi:10.1061/(ASCE)ME.1943-5479.0000507

Cheng, J. C., \& Das, M. (2014). A BIM-based web service framework for green building energy simulation and code checking. Journal of Information Technology in Construction (ITcon), 19(8), 150-168.

Davis, F. D. (1993). User Acceptance of information technology: system characteristics, user perceptions and behavioral impacts. International Journal of Man-Machine Studies, 38(3), 475-487.

Feng, Y. P. (2006). Application of Information Technology in Construction Management Paper presented at the The CRIOCM 2006 International Symposium on "Advancement of Construction Management and Real Estate", Beijing, China.

Godoe, P., \& Johansen, T. S. (2012). Understanding Adoption of New Technologies: Technology Readiness and Technology Acceptance as An Integrated Concept. Journal of European Psychology Students, 3.

Hammond, R. S., Nawari, N. O., \& Walters, B. (2014). BIM in Sustainable Design: Strategies for Retrofitting/Renovation. COMPUTING IN CIVIL AND BUILDING ENGINEERING, 19691977.

Ibrahim, N. H. (2013). Reviewing the Evidence: Use of Digital Collaboration Technologies in Major Building and Infrastructure Projects. Journal of Information Technology in Construction, 18, 40-63.

Ilhan, B., \& Yaman, H. (2016). Green building assessment tool (GBAT) for integrated BIM-based design decisions. Automation in Construction, 70, 26-37.

Irizarry, J., Gheisari, M., \& Walker, B. N. (2012). Usability Assessment of Drone Technology As Safety Inspection Tools. Journal of Information Technology in Construction, 17, 194-212.

Jiang, S., \& Lei, W. (2014). The Application of BIM in Green Building Energy Saving: Take Helsinki Music Center as an Example. Advanced Materials Research, 935, 3-7.

Lin, Y.-C. (2010). Development of Web-based Teams Management System in Construction World Academy of Science, Engineering and Technology, 4(5).

Nicosia, M., Oulasvirta, A., \& Kristensson, P. O. (2014). Modeling the Perception of User Performance. Paper presented at the SIGCHI Conference on Human Factors in Computing Systems, Toronto, Ontario, Canada.

Nunnally, J. C. (1978). Psychometric theory (2nd ed.). New York:: McGraw-Hill.

Park, S.-H., Lee, L., \& Yi, M. Y. (2011). Group-level Effects of Facilitating Conditions on Individual Acceptance of Information Systems. Inf Technol Manag, 12, 315-334. 
Petri, I., Beach, T., Rezgui, Y., Wilson, I. E., \& Li, H. (2014). Engaging Construction Stakeholders With Sustainability Through a Knowledge Harvesting Platform. Computers in Industry, 65, 4449-4469.

Setareh, M., Bowman, D. A., \& Kalita, A. (2005). Development of a Virtual Reality Structural Analysis System Journal of Architectural Engineering, 11(4), 156-164.

Shelton, J., Martek, I., \& Chen, C. (2016). Implementation of innovative technologies in small-scale construction firms: Five Australian case studies. Engineering, Construction and Architectural Management, 23(2), 177-191.

Snow, C. (2016). The Truth About Drones in Construction and Infrastructure Inspection. Retrieved from

Son, H., Lee, S., \& Kim, C. (2015). What Drives the Adoption of Building Information Modelling in Design Organizations? An Empirical Investigation of the Antecedents Affecting Architects' Behavioral Intentions. Automation in Construction, 49, 92-99.

Succar, B., \& Kassem, M. (2015). Macro-BIM Adoption: Conceptual Structures. Automation in Construction, 57, 64-79.

Venkatesh, V., \& Davis, F. D. (2000). A Theoretical Extension of the Technology Acceptance Model: Four Longitudinal Field Studies. Management Science, 46(2), 186-204.

Venkatesh, V., Morris, M. G., Davis, G. B., \& Davis, F. D. (2003). User Acceptance of Information Technology: Toward a Unified View. MIS Quarterly, 27(3), 425-478.

Wang, G., \& Cao, D. (2010). Research on the project-level influencing factors on information technology implementation in construction industry. Paper presented at the International Conference on Management and Service Science (MASS), TBD Wuhan, China.

Wong, J. K., Li, H., Wang, H., Huang, T., Luo, E., \& Li, V. (2013). Toward low-carbon construction processes: the visualisation of predicted emission via virtual prototyping technology. Automation in Construction, 33, 72-78.

Yang, L. (2011). Some Thoughts on the Development of Digital Technology in the Construction Industry. Advanced Materials Research, 243-249, 6637-6643.

Zhao, D., \& Lucas, J. (2015). Virtual Reality Simulation for Construction Safety Promotion. International Journal of Injury Control and Safety Promotion, 22(1), 57-67. 